\title{
Assessing trends in insured losses from floods in Spain 1971-2008
}

\author{
J. I. Barredo ${ }^{1}$, D. Saurí ${ }^{2}$, and M. C. Llasat ${ }^{3}$ \\ ${ }^{1}$ European Commission - Joint Research Centre, Institute for Environment and Sustainability, Ispra, Italy \\ ${ }^{2}$ Department of Geography, Autonomous University of Barcelona, Bellaterra, Spain \\ ${ }^{3}$ GAMA, Department of Astronomy and Meteorology, University of Barcelona, Barcelona, Spain
}

Correspondence to: J. I. Barredo (jose.barredo@jrc.ec.europa.eu)

Received: 29 November 2011 - Revised: 31 January 2012 - Accepted: 19 February 2012 - Published: 25 May 2012

\begin{abstract}
Economic impacts from floods have been increasing over recent decades, a fact often attributed to a changing climate. On the other hand, there is now a significant body of scientific scholarship all pointing towards increasing concentrations and values of assets as the principle cause of the increasing cost of natural disasters. This holds true for a variety of perils and across different jurisdictions. With this in mind, this paper examines the time history of insured losses from floods in Spain between 1971 and 2008. It assesses whether any discernible residual signal remains after adjusting the data for the increase in the number and value of insured assets over this period of time. Data on insured losses from floods were sourced from Consorcio de Compensación de Seguros (CCS). Although a public institution, CCS compensates homeowners for the damage produced by floods, and thus plays a role similar to that of a private insurance company. Insured losses were adjusted using two proxy measures: first, changes in the total amount of annual surcharges (premiums) paid by customers to CCS, and secondly, changes in the total value of dwellings per year. The adjusted data reveals no significant trend over the period 1971-2008 and serves again to confirm that at this juncture, societal influences remain the prime factors driving insured and economic losses from natural disasters.
\end{abstract}

\section{Introduction}

Economic impacts from flood disasters have been increasing over recent decades. However, despite the fact that the underlying causes of such increase are often attributed to a changing climate, scientific evidence points to increasing exposure and vulnerability ${ }^{1}$ as the main factors responsible for the

1 According to the United Nations International Strategy for Disasters Reduction (UNISDR, 2009: UNISDR Terminology on Disaster Risk Reduction, United Nations International Strategy for Disaster Reduction, Geneva, 30) the term vulnerability considers increase in losses (e.g. Barredo, 2009, 2010; Crompton and McAneney, 2008; Neumayer and Barthel, 2011; Pielke Jr. et al., 2008; Pielke Jr. and Landsea, 1998). Bouwer (2011a) provides a convenient summary of most of this literature. With this in mind, this paper examines the time history of insured losses from floods in Spain between 1971 and 2008. It assesses whether any discernible residual signal remains after adjusting the data for the increase in the number and value of insured assets over this period of time.

Flood damages result from the interplay of societal and hydro-meteorological factors. This being the case, we distinguish between hydrologic floods and damaging floods. Hydrologic floods may be characterised by extreme water levels that do not produce significant damage, as would be the case if they occurred in areas of low population. Damaging floods or flood disasters are those floods producing economic damage (Pielke Jr. and Downton, 2000). The outcomes of such disasters are influenced by the location of exposed assets and may be aggravated by poor land planning decisions (Burby, 2006). Evaluation of this complex interaction necessitates first accounting explicitly for the socio-economic drivers before the attribution of residual trends to other factors such as anthropogenic climate change (Pielke Jr. and Downton, 2000; Rosenzweig et al., 2007). In particular, trends of insured losses are affected by factors such as the increase in the number and value of insured assets in at-risk zones and insurance penetration, the proportion of assets that have insurance covering flood damage. Failing to adjust for such time-variant socio-economic factors produces loss amounts that are not comparable over time and an "apples versus oranges" comparison.

\footnotetext{
"the characteristics and circumstances of a community, system or asset that make it susceptible to the damaging effects of a hazard", while the term exposure includes "people, property, systems, or other elements present in hazard zones that are thereby subject to potential losses; measures of exposure can include the number of people or types of assets in an area."
} 
An analysis of the evolution of hydrologic floods would require having river discharge history as well as any change that might affect the hydrologic and hydraulic regimes such as land use, forest cover and so on (Lang and Coeur, 2002). Although there is strong evidence of changes in the European climate (Rosenzweig et al., 2007), upward trends in extreme river discharge have been found in only a few European basins in Germany (Petrow and Merz, 2009) and the Swiss Alps (Allamano et al., 2009). At a continental level, there is no conclusive evidence suggesting an increase of hydrologic floods (Glaser and Stangl, 2003; Kundzewicz et al., 2005; Kundzewicz et al., 2007; Lindström and Bergström, 2004; Macklin and Rumsby, 2007; Mudelsee et al., 2003; Villarini et al., 2012).

In Spain there is no evidence of an increase of hydrologic floods as a consequence of anthropogenic climate change (ACA, 2009; Benito et al., 2005; Llasat et al., 2005; Témez Peláez, 2006). The most comprehensive assessment endorsed by the Spain's Ministry of Environment (Benito et al., 2005) has identified two periods in the 20th century, 1930-1950 and 1960-1980, with increased magnitude and frequency of floods in Atlantic basins and with a decrease in the peak discharges of extraordinary floods in the last $25 \mathrm{yr}$. A larger variability was observed in the Mediterranean basins with maximum discharges registered in 1982 and 1987 and a reduction in discharge from the 1990s. Damaging floods in terms of human losses appear to have decreased in large river basins and increased in smaller basins such as those in the Mediterranean areas prone to flash flooding episodes as well as in urban areas. However, these changes can be related to the presence of dams and a major displacement of the population to more flood prone areas in the coast (Llasat et al., 2008).

Analysis of the series of annual maximum discharges recorded at gauging stations in Spain indicates a decrease in the peaks of floods over the last $40 \mathrm{yr}$. However, this decrease in peak discharge could reasonably be a consequence of the around 1000 dams constructed in the 1950s and 1960s for water supply and hydro-electricity. Caution is needed when looking for a climate change signature in flood discharges recorded in the last $30 \mathrm{yr}$ in regulated rivers (Benito et al., 2005). The lack of evidence of an increase of hydrologic floods in Spain supports the hypothesis that a positive trend in the increase of flood losses should be attributed to societal shifts in the exposed areas. And this will likely remain so as long as the geophysical data do not show any systematic trend (Bouwer, 2011a).

Socio-economic changes in Spain in the last four decades have been significant and to ignore these changes in the context of an examination of flood damage would be negligent. In the early 1970s, the Spanish population and economy still retained many of the characteristics of an underdeveloped country: low per capita income; relatively high proportion of workers employed in agriculture; large migratory flows to other countries; important regional disparities, and a productive sector still heavily controlled by the authoritarian state. In 1971, the GDP amounted to the equivalent of 269 billion in constant Euros of 2008 (at Purchasing Power Parity -PPP-) (The Conference Board, 2011) and Spain had a population of 34 million, a high birth rate and important internal migratory shifts from the agrarian south to the industrial centres of Madrid, Catalonia and the Basque Country. In political terms, the death of Francisco Franco in 1975 heralded the transition to democracy. The economy still grew relatively fast until the first oil shock of 1974. But from the mid 1970s to mid 1980s it languished under the effects of the oil crisis and then a massive reorganization of the public sector and the dismantling of obsolete industrial activities in the first half of the 1980s. In 1986 Spain became a Member State of the European Union. The population reached 45.9 million people in 2008, a growing proportion of which were immigrants from North Africa and Latin America. The GDP in 2008 had grown to around 1 trillion Euro and GDP per capita to Euro 20751 (7869 in 1971), all in constant Euros of 2008 (at PPP). To summarise, the last four decades have witnessed important structural and social changes in Spain (de la Dehesa, 2003; García Delgado, 2005; OECD, 2010).

The paper is organised in five sections. Section 2 analyses the available data. Section 3 describes the methodology used for adjusting insured flood losses. Section 4 shows the results and assesses the trends of adjusted losses. This is followed by a discussion section that examines the explanatory drivers of insured flood losses and the limitations of the method and the available data.

\section{Data}

Data on insured flood losses were obtained from the statistical series of Consorcio de Compensación de Seguros (CCS) (2009). CCS is an institution of Spain's Economics and Finance Ministry founded in 1954 after a provisional period that begun in 1941. Its raison d'être is to compensate for the losses produced by natural and socio-political risks. Although a public institution, CCS has its own legal personality and is subject to laws governing private sector firms.

CCS also covers losses from disasters when the market does not assume these losses. This is the case for floods since most private insurance companies do not cover this hazard (CCS, 2010); these are entirely covered by CCS. In fact, floods represent $81 \%$ of the losses from weather-driven disasters in 1971-2008 (CCS, 2009).

An extraordinary risks cover is compulsory in the policies covering damage from natural events such as floods; however, the underwriting of this peril is optional. The price of the cover offered by CCS is a surcharge on the sum insured in policies issued by private sector insurance firms. Premiums are collected by the private firm and the surcharge transferred 
to CCS. Funding for CCS comes from the mentioned surcharges (Machetti, 2005).

Annual insured losses from floods are available for the period 1971-2008. CCS covers losses from several flood types: water logging as consequence of heavy rainfall, snow- and ice-melt, and lake, riverine and coastal floods. The available series is measured in constant Euros as of 2008 (adjusted for inflation by CCS). The series includes direct losses from $e x$ traordinary floods, and from 2004 business interruption as result of direct damage (BOE, 2004, 2006).

The CCS definition of extraordinary in respect to flood changed in 1986. Before that year, an official declaration of catastrophe zone was required for a flood to be defined as extraordinary and then be covered by CCS. From 1986 onwards, an official declaration has not been needed; flood disasters have been automatically covered by CCS (CCS, 2010). The change in the definition of an extraordinary flood and the inclusion of business interruption in the losses might reasonably lead to an increase in the insured losses after 1986 and 2004, respectively.

Figure 1 shows the original insured losses from floods as provided by CCS. The available data is not disaggregated per flood event. This rules out using a more sophisticated normalisation assessment of the influence of socio-economic changes in the loss history (Barredo, 2009, 2010; Pielke Jr. et al., 2008).

\section{Methods}

While exposure to flood damage changes over time as a consequence of flood plain occupancy and flood mitigation policies, data on the value and location of assets exposed to flood is not usually available. For this reason, further analysis often requires using proxy measures to account for changing exposure (Barredo, 2009; Pielke Jr. and Downton, 2000). Here we employ two different surrogate measures to produce two different metrics. In the first case, the metric is the aggregated flood claims losses per million Euros of paid insurance surcharges. The second metric observed was the flood claims losses per million Euros of total value of dwellings. We assume that the overall national trends in surcharges paid to CCS and the value of dwellings faithfully reflect actual trends in these variables in zones impacted by floods.

Data on paid surcharges per year was sourced from CCS (2009). This series is a useful proxy for increasing value of assets exposed and insurance penetration over time. The series represents the total surcharge paid by insurance customers to CCS. In 2008 the total value of surcharges was Euro 635 million (hereafter and unless indicated otherwise, Euros will be expressed in constant 2008 values after adjusting for inflation), distributed across different lines of business as follows: $42 \%$ housing and offices, $12 \%$ business, $28 \%$ industry and civil works and $18 \%$ motor vehicles (CCS, 2009).

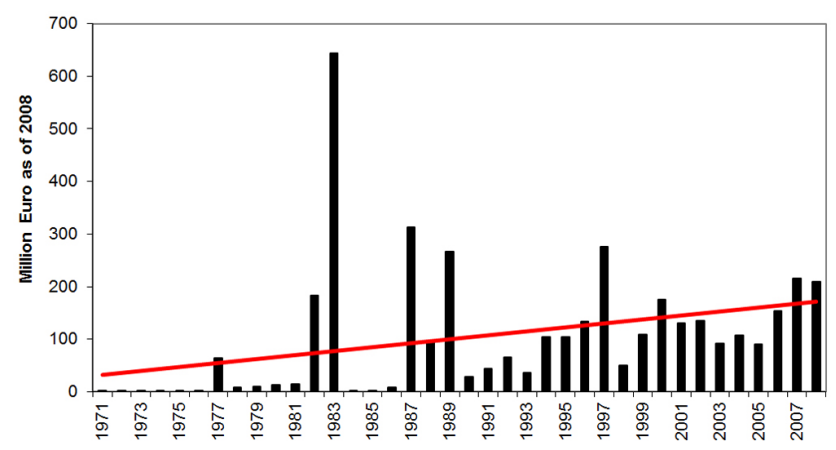

Fig. 1. Spain's flood insured losses 1971-2008 adjusted for inflation to 2008 Euros (linear trend in red).

The method used by CCS for calculating surcharges changed in January 1987. Before this date, the surcharges were calculated on the basis of a ratio of the premium of the ordinary insurance policy. From that date onwards the surcharge, with different rates according to the kind of good covered, has been applied on the capital insured in the ordinary policy. This might lead to some differences in the series before and after that date, a point to which we shall return below.

Another limitation of the series of paid surcharges is the potential effect that increasing aggregated flood claims losses over time may produce. Paid surcharges increase over time because of a number of factors, i.e. increasing value of insured assets, increasing number of assets insured, increases in losses claimed. For the last factor, we can hypothetically assume that when aggregated flood claims losses increase over time, one may expect (at least in the long term) a subsequent increase in paid surcharges to cover these costs. If this hypothesis becomes true, then the ratio of aggregated flood claims losses per paid insurance surcharges should remain constant over time.

For assessing the above-mentioned potential limitations of the series of surcharges, a comparison was done with the second measure (dwellings value) that is independent from the surcharges. Figure 2 shows that the series of the two proxies used for adjusting the insured flood losses (surcharges paid and dwellings value) are in reasonable accord with each other. This indicates first, that for the mentioned hypothesis to be true, one would expect a divergent trend between both measures, something not evident in Fig. 2. On the contrary, both measures exhibit a similar evolution over time and therefore the effect of increasing flood claims losses seems not relevant on the surcharges. And second, that despite the above mentioned change in the calculation of surcharges, this series is a reasonably good proxy for the changes in the value of exposed assets and insurance penetration over time.

The series of national value of dwellings is the product of the number of dwellings and the average value of dwellings. Data on the average value of dwellings was sourced from the 


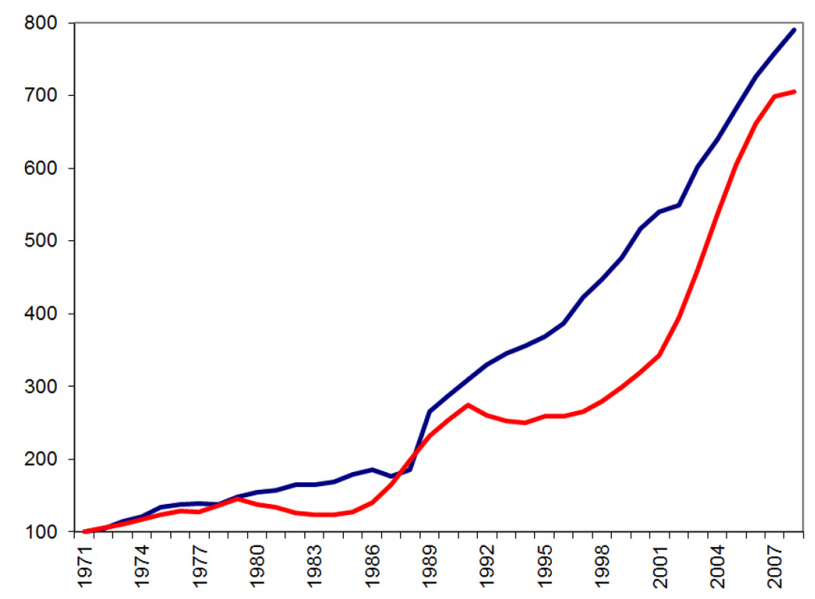

Fig. 2. Surcharges (premiums) paid to the Consorcio de Compensación de Seguros (in blue) and value of dwellings (in red) in Spain 1971-2008 adjusted for inflation to 2008 (index 1971=100).

statistical series of the Spanish Ministry of Infrastructure ${ }^{2}$ and the Bank of Spain (Martínez Pagés, 2010; Martínez Pagés and Maza, 2003). These data represent the national average value of a square metre of dwelling without contents. The available series covers the period 1976-2009. For those years prior to 1976 , the data was adjusted for the average annual price increase observed between 1976 and 1980 of 15.35 Euro $\mathrm{m}^{-2} \mathrm{yr}^{-1}$.

The number of dwellings per year was sourced from the Spanish Statistical Office (INE) and from the Bank of Spain. Although we consider the series of national value of dwellings a useful proxy of the increasing value of exposed assets over time, there are some limitations worth mentioning. First, the series represents variations only in the value of dwellings, and thus excludes changes in value of contents or changes in other assets such as industry and business. And second, the series underestimates the effect of increasing insurance penetration in the Spanish market. A potential effect of this limitation is that this measure may tend to overestimate adjusted losses in more recent years, therefore contributing to an increasing positive trend in the adjusted losses. The comparison shown in Fig. 2 between dwellings' value and paid surcharges (that account for insurance penetration) is useful for evaluating potential bias resulting from the mentioned limitation. The similarity of both measures indicates that the effect of changing insurance penetration over time does not hamper the use of the value of dwellings. Otherwise one should expect divergent trends between both measures.

Finally, we examined the statistical significance of the trends observed in the series of original and adjusted losses. Annual losses were regressed linearly on its year: the null hypothesis is that the slope of the regression equation is equal to zero, if this hypothesis can be rejected at the $5 \%(\alpha=0.05)$ level or lower, the trend is statistically significant.

\footnotetext{
${ }^{2}$ Accessed on October 2010 at http://www.mviv.es/es/
}

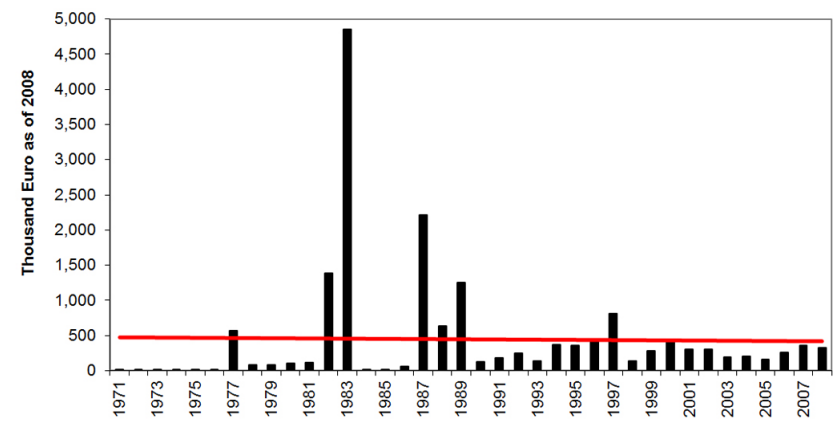

Fig. 3. Spain's flood insured losses 1971-2008 per million Euros premium paid adjusted for inflation to 2008 (linear trend in red).

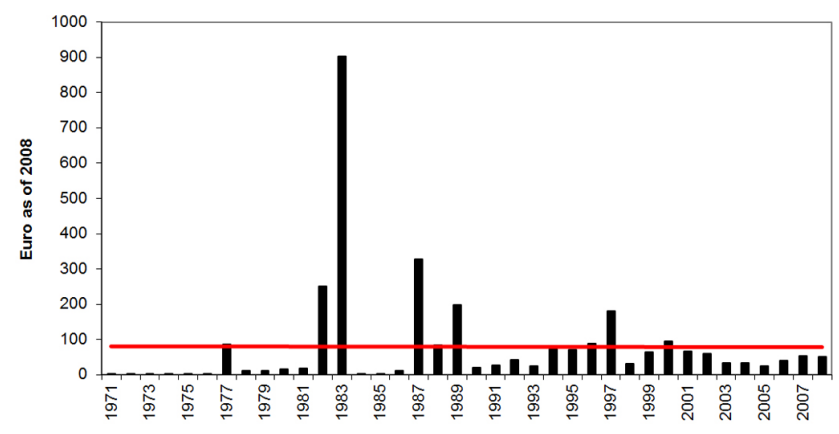

Fig. 4. Spain's flood insured losses 1971-2008 per million Euros dwelling value adjusted for inflation to 2008 (linear trend in red).

\section{Results}

Figure 1 shows the annual distribution of insured flood losses in Spain in constant 2008 Euros. Overall losses in the period are around 3.9 billion Euro, and the annual average loss is 102 million Euro. The series is characterised by high inter-annual variability - standard deviation of 125 million Euro. 1983 registered the highest losses followed by 1987 and 1997. The unadjusted series shows a statistically significant increasing trend of $4.6 \%$ per year from 1971 to 2008 (Table 1).

Figures 3 and 4 show the losses adjusted for surcharges paid and for national value of dwellings respectively. In neither series is there any trend evident over time. Furthermore, the series exhibit a statistically insignificant marginal decreasing trend of $-0.3 \%$ and $-0.1 \%$ (Table 1 ). In the adjusted series, 1983 registers the highest losses followed by 1987 and 1982.

1983 appears as the costliest year (in either the raw data or the adjusted time series) due to the effects of the floods in the Basque Country, Cantabria and Navarra that caused insured losses of Euro 623 million (Piserra et al., 2005). Also, the losses caused by that disaster exceed the annual average losses by a factor of 6.1. Hence the large losses of this event, which occurred in the first half of the assessment period, could pivot the adjusted trend lines towards decreasing 
Table 1. Annual rate of change in the series of losses and test of statistical significance.

\begin{tabular}{lrrr}
\hline & t-value & $\begin{array}{r}\text { p-value } \\
\begin{array}{r}\text { Annual rate } \\
\text { of change }\end{array}\end{array}$ & \\
\hline Original losses (Fig. 1) & 2.14 & 0.039 & $+4.63 \% *$ \\
Losses adjusted for surcharges paid (Fig. 3) & -0.11 & 0.913 & $-0.30 \%$ \\
Losses adjusted for dwellings' value (Fig. 4) & -0.03 & 0.976 & $-0.10 \%$ \\
Losses adjusted for surcharges paid excluding the major flood of 1983 & 0.81 & 0.423 & $+1.71 \%$ \\
Losses adjusted for dwellings' value excluding the major flood of 1983 & 1.09 & 0.283 & $+2.21 \%$ \\
\hline
\end{tabular}

* Statistically significant at $5 \%(\alpha=0.05)$

losses. For assessing the statistical influence of this outlier, we calculated the trend line and statistical significance of the adjusted series excluding the losses of this event: the result is a statistically insignificant annual increase of $1.71 \%$ and $2.21 \%$ in the adjusted series (Table 1 ).

\section{Discussion and conclusions}

The most salient feature of our analyses is the absence of a significant positive trend in the adjusted insured flood losses in Spain. This suggests that the increasing trend in the original losses is explained by socio-economic factors, such as the increases in exposed insured properties, value of exposed assets and insurance penetration. In short, there is no residual signal that remains after adjusting for these factors and the analysis rules out a discernible influence of anthropogenic climate change on insured losses. This is consistent with the lack of a positive trend in hydrologic floods is Spain in the last $40 \mathrm{yr}$.

It is noteworthy that the value of dwellings in Spain has increased in average by a factor of 7.1 from 1971 to 2008 . This is in line with a 7.9 factor increase in surcharges paid to CCS over the same period (Fig. 2). These numbers reflect the magnitude of the socio-economic changes that have occurred in Spain over the last few decades. Interestingly, the increase in these two factors is much greater than the increase in the national GDP of 3.5 from 1971 to 2008 (The Conference Board, 2011). In other words, values of exposed assets have escalated two times faster than the national GDP.

The results of this study are consistent with other studies in this field in many jurisdictions in other regions of the world (Bouwer, 2011a) and with other studies that have adjusted flood losses at the country level such as in the US (Pielke Jr. and Downton, 2000), Italy (Lastoria et al., 2006) and Switzerland (Hilker et al., 2009). From a global perspective, the increasing exposure of people and economic assets is recognised by the IPCC (2011) as the major cause of the long-term increases in economic losses from weather-related disasters. The IPCC reports that long-term trends in economic losses after adjusting for wealth and population cannot be attributed to climate change. However, climate change in the future will most likely contribute to an increase in losses. In Spain Piserra et al. (2005) have attributed the increase of insured losses to higher insurance penetration, the increases of exposed insured assets and to the higher volume of capital insured. At the regional level in Catalonia, increases in flood occurrence have been attributed to factors such as increased urbanisation in recent years, changes in geomorphological or hydrological river conditions or improvements in the reporting of disasters (Barnolas and Llasat, 2007; Llasat et al., 2009a, b).

It is worth noting that more robust conclusions would demand a longer time-series of flood losses. The series available for this study covers almost $40 \mathrm{yr}$, however longer series would be needed to explore, for instance, the possible role of decadal-scale fluctuations in climate variability. Recent evidence using future projection of hurricane activity in a warming climate suggest that the effects of a statistically discernible impact of anthropogenic climate change in the trend of US hurricane losses could take between 120 and $550 \mathrm{yr}$, with an 18-model ensemble based signal of $260 \mathrm{yr}$ (Crompton et al., 2011). In Europe, it is projected that anthropogenic climate change will most likely contribute to an increase in flood hazard and losses during this century (Feyen et al., 2011).

A limitation of this study is that reductions in vulnerability (e.g. building techniques or improvement of the drainage system) are not considered. While the increase in wealth exposed is well captured by the two proxies used, changes in vulnerability are harder to quantify (Bouwer, 2011a) and no standardised data on flood mitigation measures are available. Nevertheless, in the hypothetical case that a common vulnerability reduction standard had been implemented at national level, a bias is not evident in the adjusted trends of losses due to this limitation. Otherwise, under this hypothetical assumption, in absence of an increase in hydrologic floods (hazard) and after adjusting the losses for the effect of changes in exposed wealth (exposure), one would expect a more consistent decreasing trend of adjusted losses due to the effect of vulnerability reduction; something not evident in the adjusted losses. Nevertheless, the assumption of a common vulnerability reduction standard is hardly applicable in our case. Moreover, different regions may implement 
different strategies towards flood mitigation. The question remains as to how large an influence this might be given considering that the value of exposed assets has grown by some $700 \%$ in the last four decades. Furthermore, the implementation of mitigation measures for floods are often taken after large events and in the specific region of occurrence (Bouwer, 2011b) and often lead to bigger losses in more extreme events by encouraging development in vulnerable locations (Burby, 2006; Roche et al., 2010).

Some changes in the time series of insured losses could be an additional source of uncertainty. Prior to 1986, an official declaration of catastrophe zone was required for a flood to be defined as extraordinary and eligible for coverage by the CCS, and from 2004 onwards, losses resulting from business interruption have been covered. We expected that the effect of these changes would have been to increase the losses over the second part of the time-series, a feature not evident in the adjusted losses.

Considerable uncertainty remains because of limitations in the time-series of flood losses, difficulties for measuring exposure and vulnerability and the complex dynamics driving changes in flood hazard (Svensson et al., 2006). Notwithstanding these limitations, the methodology implemented in this study provides an effective approach for adjusting insured flood losses for known socio-economic influences. After adjusting for these, there remains no residual signal that might be attributable to other influences, in particular anthropogenic climate change. A corollary to this result is that it points to the importance of risk-informed land planning and other factors that are under our control as means to reduce this nation's exposure to damaging floods.

Acknowledgements. The authors would like to thank the anonymous referee for the helpful suggestions during the review of the manuscript and John McAneney for his advice and guidance. We are also grateful to the persons and organisations that provided the data for the preparation of this study: Jorge Martínez Pagés from Banco de España, Alfonso Nájera Ibáñez from Consorcio de Compensacion de Seguros, and Alicia Ferrándiz de Oro from Dirección General de Seguros y Fondos de Pensiones del Ministerio de Economía y Hacienda. This study has been partially developed within the framework of the HYMEX project. The views expressed are purely those of the writers and may not in any circumstance be regarded as stating an official position of the European Commission.

Edited by: T. Glade

Reviewed by: J. McAneney and another anonymous referee

\section{References}

ACA: Agua y Cambio Climático - Diagnosis de los impactos previstos en Cataluña, Agencia Catalana del Agua (ACA), Barcelona, 329 pp., 2009.

Allamano, P., Claps, P., and Laio, F.: Global warming increases flood risk in mountainous areas, Geophys. Res. Lett., 36, L24404, doi:10.1029/2009GL041395, 2009.
Barnolas, M. and Llasat, M. C.: A flood geodatabase and its climatological applications: the case of Catalonia for the last century, Nat. Hazards Earth Syst. Sci., 7, 271-281, doi:10.5194/nhess-7271-2007, 2007.

Barredo, J. I.: Normalised flood losses in Europe: 19702006, Nat. Hazards Earth Syst. Sci., 9, 97-104, doi:10.5194/nhess-9-972009, 2009.

Barredo, J. I.: No upward trend in normalised windstorm losses in Europe: 1970-2008, Nat. Hazards Earth Syst. Sci., 10, 97-104, doi:10.5194/nhess-10-97-2010, 2010.

Benito, G., Barriendos, M., Llasat, C., Machado, M., and Thorndycraft, V.: 15. Impacts on natural hazards of climatic origin, in: A Preliminary Assessment of the Impacts in Spain due to the Effects of Climate Change, edited by: Moreno Rodríguez, J. M., Ministerio de Medio Ambiente, Madrid, 507-528, 2005.

BOE: Real Decreto 300/2004, de 20 de febrero, por el que se aprueba el Reglamento del seguro de riesgos extraordinarios, Boletín Oficial del Estado, 8614-8618, 2004.

BOE: Real Decreto 1265/2006, de 8 de noviembre, por el que se modifica el Reglamento del seguro de riesgos extraordinarios, aprobado por el Real Decreto 300/2004, de 20 de febrero, Boletín Oficial del Estado, 40879-40882, 2006.

Bouwer, L. M.: Have Disaster Losses Increased Due to Anthropogenic Climate Change?, B. Am. Meteorol. Soc., 92, 39-46, 2011 a.

Bouwer, L. M.: Reply, B. Am. Meteorol. Soc., 92, 792-793, 2011 b.

Burby, R.: Hurricane Katrina and the Paradoxes of Government Disaster Policy: Bringing About Wise Governmental Decisions for Hazardous Areas, Ann. Am. Acad. Polit. S. S., 604, 171-191, 2006.

CCS: Estadística - Riesgos extraordinarios - Serie 19712008, Consorcio de Compensacion de Seguros, Ministerio de Economía y Hacienda, Madrid, 161 pp., 2009.

CCS: La cobertura de los riesgos extraordinarios en España, Consorcio de Compensacion de Seguros, Ministerio de Economía y Hacienda, Madrid, 13 pp., 2010.

Crompton, R. P. and McAneney, K. J.: Normalised Australian insured losses from meteorological hazards: 1967-2006, Environ. Sci. Policy, 11, 371-378, 2008.

Crompton, R. P., Pielke Jr., R. A., and McAneney, K. J.: Emergence timescales for detection of anthropogenic climate change in US tropical cyclone loss data, Environ. Res. Lett., 6, 014003, doi:10.1088/1748-9326/6/1/014003, 2011.

de la Dehesa, G.: Balance de la economía española en los últimos 25 años, Información Comercial Española, 811, 53-79, 2003.

Feyen, L., Dankers, R., Bódis, K., Salamon, P., and Barredo, J. I.: Fluvial flood risk in Europe in present and future climates, Climatic Change, in press, 1-16, 2011.

García Delgado, J. L.: Lecciones de economía española, Civitas, Madrid, 440 pp., 2005.

Glaser, R. and Stangl, H.: Historical floods in the Dutch Rhine Delta, Nat. Hazards Earth Syst. Sci., 3, 605-613, doi:10.5194/nhess-3-605-2003, 2003.

Hilker, N., Badoux, A., and Hegg, C.: The Swiss flood and landslide damage database 19722007, Nat. Hazards Earth Syst. Sci., 9, 913-925, doi:10.5194/nhess-9-913-2009, 2009.

IPCC: Summary for Policymakers. In: Intergovernmental Panel on Climate Change Special Report on Managing the Risks of Extreme Events and Disasters to Advance Climate Change Adapta- 
tion, edited by: Field, C. B., Barros, V., Stocker, T. F., Qin, D., Dokken, D., Ebi, K. L., Mastrandrea, M. D., Mach, K. J., Plattner, G.-K., Allen, S. K., Tignor, M., and P. M. Midgley, United Kingdom and New York, NY, USA, 29 pp., 2011.

Kundzewicz, Z. W., Graczyk, D., Maurer, T., Piñskwar, I., Radziejewski, M., Svensson, C., and Szwed, M.: Trend detection in river flow series: 1 . Annual maximum flow, Hydrol. Sci. J., 50, 797-810, 2005.

Kundzewicz, Z. W., Mata, L. J., Arnell, N. W., Döll, P., Kabat, P., Jiménez, B., Miller, K. A., Oki, T., Sen, Z., and Shiklomanov, I. A.: Freshwater resources and their management, Climate Change 2007: Impacts, Adaptation and Vulnerability. Contribution of Working Group II to the Fourth Assessment Report of the Intergovernmental Panel on Climate Change, edited by: Parry, M. L., Canziani, O. F., Palutikof, J. P., van der Linden, P. J., and Hanson, C. E., Cambridge University Press, Cambridge, UK, 173-210, 2007.

Lang, M. and Coeur, D.: Flood knowledge: history, hydraulics and hydrology. Case study on three French rivers, Colloque FrancoChinois sur la protection et l'utilisation durable de la ressource en eau, Chinese-French Conference on water resources, Shanghai, 96-102, 2002.

Lastoria, B., Simonetti, M. R., Casaioli, M., Mariani, S., and Monacelli, G.: Socio-economic impacts of major floods in Italy from 1951 to 2003, Adv. Geosci., 7, 223-229, doi:10.5194/adgeo-7223-2006, 2006.

Lindström, G., and Bergström, S.: Runoff trends in Sweden 18072002, Hydrol. Sci. J., 49, 69-83, 2004.

Llasat, M.-C., Barriendos, M., Barrera, A., and Rigo, T.: Floods in Catalonia (NE Spain) since the 14th century, Climatological and meteorological aspects from historical documentary sources and old instrumental records, J. Hydrol., 313, 32-47, 2005.

Llasat, M. C., López, L., Barnolas, M., and Llasat-Botija, M.: Flash-floods in Catalonia: the social perception in a context of changing vulnerability, Adv. Geosci., 17, 63-70, doi:10.5194/adgeo-17-63-2008, 2008.

Llasat, M. C., Llasat-Botija, M., Barnolas, M., Lṕpez, L., and Altava-Ortiz, V.: An analysis of the evolution of hydrometeorological extremes in newspapers: the case of Catalonia, 1982-2006, Nat. Hazards Earth Syst. Sci., 9, 1201-1212, doi:10.5194/nhess-9-1201-2009, 2009a.

Llasat, M. C., Llasat-Botija, M., and López, L.: A press database on natural risks and its application in the study of floods in Northeastern Spain, Nat. Hazards Earth Syst. Sci., 9, 2049-2061, doi:10.5194/nhess-9-2049-2009, 2009b.

Machetti, I.: The Spanish Experience in the Management of Extraordinary Risks, Including Terrorism, in: Catastrophic Risks and Insurance, edited by: OECD, Policy Issues in Insurance, OECD, Paris, 337-348, 2005.

Macklin, M. G. and Rumsby, B. T.: Changing climate and extreme floods in the British uplands, T. I. Brit. Geogr., 32, 168-186, 2007.

Martínez Pagés, J.: House prices in Spain 1976-2009 (personal communication), Banco de España, 2010.
Martínez Pagés, J. and Maza, L. Á.: Analysis of house prices in Spain, Banco de España, Madrid, Working paper 0307, 45 pp., 2003.

Mudelsee, M., Borngen, M., Tetzlaff, G., and Grunewald, U.: No upward trends in the occurrence of extreme floods in central Europe, Nature, 425, 166-169, 2003.

Neumayer, E. and Barthel, F.: Normalizing economic loss from natural disasters: A global analysis, Global Environ. Chang., 21, 13-24, 2011.

OECD: OECD Economic Surveys: Spain 2010, Organisation for Economic Co-operation and Development Paris, 148 pp., 2010.

Petrow, T. and Merz, B.: Trends in flood magnitude, frequency and seasonality in Germany in the period 1951-2002, J. Hydrol., 371, 129-141, 2009.

Pielke Jr., R. A. and Downton, M. W.: Precipitation and Damaging Floods: Trends in the United States, 1932-97, J. Climate, 13, 3625-3637, 2000.

Pielke Jr., R. A., and Landsea, C. W.: Normalized Hurricane Damages in the United States: 1925-95, Weather Forecast., 13, 621631, 1998.

Pielke Jr, R. A., Gratz, J., Landsea, C. W., Collins, D., Saunders, M. A., and Musulin, R.: Normalized Hurricane Damage in the United States: 1900-2005, Nat. Hazards Rev., 31, 29-42, 2008.

Piserra, M. T., Nájera, A., Lapieza, R., Loster, T., Wirtz, A., Soriano, B., and Sáez, J.: 15. Impacts on the Insurance Sector, in: A Preliminary Assessment of the Impacts in Spain due to the Effects of Climate Change, edited by: Moreno Rodríguez, J. M., Ministerio de Medio Ambiente, Madrid, 663-698, 2005.

Roche, K., McAneney, K. J., and van den Honert, R.: Policy options for managing flood insurance, Environ. Hazards, 9, 369378, 2010.

Rosenzweig, C., Casassa, G., Karoly, D. J., Imeson, A., Liu, C., Menzel, A., Rawlins, S., Root, T. L., Seguin, B., and Tryjanowski, P.: Assessment of observed changes and responses in natural and managed systems, Climate Change 2007: Impacts, Adaptation and Vulnerability in: Contribution of Working Group II to the Fourth Assessment Report of the Intergovernmental Panel on Climate Change, edited by: Parry, M. L., Canziani, O. F., Palutikof, J. P., van der Linden, P. J., and Hanson, C. E., Cambridge University Press, Cambridge, UK, 79-131, 2007.

Svensson, C., Hannaford, J., Kundzewicz, A. W., and Marsh, T. $\mathrm{J}$.: Trends in river floods: why is there no clear signal in observations?, Frontiers in flood research, 8th Kovacs Colloquium, UNESCO, Paris, 30 June-1 July 2006, 2006.

Témez Peláez, J. R.: Las catástrofes hidrológicas españolas y el cambio climático (Spanish Hydrological disasters and climate change), Revista de Obras Públicas, 153, 7-11, 2006.

The Conference Board: Total Economy Database, The Conference Board, available at: http://www.conference-board.org/data/ economydatabase (last access: 28 November 2011), 2011.

Villarini, G., Smith, J. A., Serinaldi, F., Ntelekos, A. A., and Schwarz, U.: Analyses of extreme flooding in Austria over the period 1951-2006, Int. J. Climatol., in press, 2012. 